\title{
Active Voice, Active Writing
}

COMMUNICATION CORNER No. 22

\author{
by Philip Yaffe
}

\section{Editor's Introduction}

Each "Communication Corner" essay is self-contained; however, they build on each other. For best results, before reading this essay and doing the exercise, go to the first essay "How an Ugly Duckling Became a Swan," then read each succeeding essay.

Knowing when to write in the active or passive voice can fundamentally improve your work, but understanding how to use either can be tricky. Keep reading to learn the difference. 


\title{
Active Voice, Active Writing
}

\author{
COMMUNICATION CORNER NO. 22
}

\section{by Philip Yaffe}

Virtually every book on good writing tells novices to "use the active voice" or "avoid the passive voice." This is good advice as far as it goes. The problem is, it goes too far. It is often as if the author believes the passive voice should be banned from language as both useless and/or detrimental. It is neither. If the passive voice had no legitimate function, how did it become part of language in the first place?

If you remember your secondary school grammar lessons (provided your native language is English), you know that among its structures there are two fundamental types of sentences: active voice and passive voice. For example:

- Active: George grew the flowers.

- Passive: The flowers were grown by George.

Schematically, you can say that in active voice, A does something that affects $\mathbf{B}$. In passive voice, $\mathbf{B}$ is affected by something done by $\mathbf{A}$.

But which is preferable?

The truth is active voice is useful when it is useful, and not useful when it isn't. Likewise, passive voice is useful when it is useful, and not useful when it isn't. However, active voice is useful much more often than passive voice, because active voice appeals more directly to how we normally think.

According to one eminent author:

"Active writing minces no words. It calls attention directly to responsible agents, stating clearly what they do and how they affect their surroundings. Passive writing wastes words. It diverts attention from responsible agents, focusing only on the effects of 'external forces' on objects and people."

Note the change in vocabulary. The author is not talking about individual active and passive sentences, but rather active and passive writing. Use of a passive sentence where it is useful enhances a text by momentarily shifting the point of view. However use of passive writing, i.e. most of a text is passive, almost never enhances because it goes counter to how we normally think and therefore how we want to receive information. 
To continue the analysis, the author asks us to picture a model. There is an agent $\mathbf{A}$ and a $\operatorname{target}$ T. A "line of action" emanates from agent $\mathbf{A}$ and ends at target $\mathbf{T}$. The active voice emphasizes the initiation of action along the line from $\mathbf{A}$ to $\mathbf{T}$. The passive voice emphasizes the receipt of action along that line.

He then adds an important caveat:

"Large variations in the degree of passivity are possible. At one extreme is the 'near passive,' which is obtained from the active by converting verbs to passive forms. At the other extreme is the 'remote passive,' which focuses on the target as the center of the universe. This type of writing hides all agents and obscures responsibility with long noun-strings. In between is the 'middle passive,' which transfers responsibility from the agent to surrounding objects but does not completely hide the agent.

"The degree of passivity in a text may be related to writers' feeling of control or influence over things around them. Active writers have a good deal of confidence in their ability to influence events and people; they radiate their confidence like the sun. By contrast, more passive writers may see themselves as victims at the center of a black hole; they attract all kinds of unsolicited debris from unseen sources."

Here are examples offered by the author to illustrate his four degrees of passivity.

\section{Active}

Frank Arthur, the president of Arthur Associates, acted hostile and angry last Friday. After work, he purposely drank too much. On the way home, he drove his car into a tree. The police forcibly removed his body and called his wife. His family scheduled his funeral Sunday. The stockholders, believing Frank committed suicide, lost confidence and drove down the price of Arthur Associates stock.

(All verbs and sentences are active voice.)

\section{Near Passive}

Frank Arthur, the president of Arthur Associates, was overwhelmed last Friday by hostility and anger. After work, he got purposely drunk. On the way home, his car was driven by him into a tree. His body was removed forcibly by the police and his wife called. A funeral was scheduled for him by his family for Sunday. Because Frank was believed by the stockholders to have committed suicide, the price of Arthur Associates' stock was driven down.

(All verbs converted to passive voice.) 


\section{Middle Passive}

Last Friday, hostility and anger invaded the President of Arthur Associates. After work, too much liquor found its way down his gullet. On the way home, the car impacted itself into a tree. The body let itself be extracted by police force and notification went to his wife. The funeral became scheduled for Sunday by the family. Because the belief of suicide inculcated the stockholders, the price of Arthur Associates stock decided to drop.

(Agency transferred to objects surrounding the target, away from the real agents.)

\section{Remote Passive}

With the advent of the last work weekday, hostility and anger feelings overwhelmed the Arthur Associates president. The use of excessive liquor consumption upon completion of his job work time occurred. An arboreal upgrowth on the employer-to-domicile vehicular infrastructure pathway was impacted by his personal transport vehicle. A corpus delecti was having automotive extraction performed on it by police activated force. The spouse was having the bad news concepts meted out during a relevant telephone dialog. The funeral was being attended the following week beginning day. It was believed suicide has been committed and the Arthur Associates stock resource received a plummeting price blow.

(No agency at all, things just befall the target.)

Obviously, some of the examples are quite extreme. However, they graphically illustrate the point.

So how can we determine the best combination of active and passive writing in a text?

This is very much like asking how long is a piece of string. It all depends on what you want to achieve. Indeed, there are some categories of texts that require passive writing, such as peerreviewed research papers.

In general, the abstract (summary of what the paper contains) is written passively to avoid appearing to be pressuring the reader into accepting the conclusions of the paper before they have actually read it. The methodology section (how the experiment or study was carried out) is also generally in passive writing, and for the same reason.

\section{Compare:}

- "We used four different types of measuring devices from four different manufacturers to gather our data." 
- "Four different types of measuring devices from four different manufacturers were used to gather our data."

However, research publications do not follow hard and fast rules. Some insist on passive writing in the abstract and methodology sections, and perhaps elsewhere. Others do not.

By way of conclusion, the author makes a ringing declaration.

"Using passive voice signals an attitude of detachment and not-taking-responsibility. The extreme passive is not something you come across much (let's hope not!), but I have occasionally come across things that are close. It is as if the writer believed that whatever happened was attracted to the target by the target itself and that no agency of any kind was involved. To speak in active voice, you need to have an attitude of taking responsibility. You won't leave your readers scratching their heads trying to figure who is making a commitmentor if anyone is at all."

I hope you are not too annoyed with me for having strung you along. I imagine you have been itching to ascertain who this "eminent author" is; I know I would have been. Well, here's the big reveal. It is Peter Denning, well-known computer scientist, author of numerous books and research papers-and coincidentally, editor-in-chief of this publication, Ubiquity, He told me of the origin of his essay.

"I wrote it in direct response to queries from quizzical students, "What do you mean by writing in active voice?' I saw that it was more than just a question of the voice of verbs. It was principally a question of attitude, i.e. how much agency the writer was prepared to acknowledge. I wanted to suggest to my students that passive writing signals that the writer doesn't want to take responsibility for implementing any of the recommendations the writer makes in the paper."

If you would like to read Peter's original 1984 essay "On Active and Passive Writing," you can download it from http://denninginstitute.com/pjd/PUBS/PassiveActive.pdf.

\section{About the Author}

Philip Yaffe was born in Boston, Massachusetts, in 1942 and grew up in Los Angeles, where he graduated from the University of California with a degree in mathematics and physics. In his senior year, he was also editor-in-chief of the Daily Bruin, UCLA's daily student newspaper. He has more than 40 years of experience in journalism and international marketing communication. At various points in his career, he has been a teacher of journalism, a reporter/feature writer with The Wall Street Journal, an account executive with a major 
international press relations agency, European marketing communication director with two major international companies, and a founding partner of a specialized marketing communication agency in Brussels, Belgium, where he has lived since 1974. He is the author of more than 30 books, which can be found easily in Amazon Kindle.

DOI: $10.1145 / 3383777$ 